\title{
BIOSYSTEMATIC STUDIES IN THE BRAZILIAN ENDEMIC GENUS HOFFMANNSEGGELLA H. G. JONES (ORCHIDACEAE:LAELIINAE): A MULTIPLE APPROACH APPLIED TO CONSERVATION
}

\author{
Christiano Franco Verola ${ }^{1,5}$, Jõ̃o Semir $^{2}$, Alexandre Antonelli $^{3}$ \\ \& INGRID $\mathrm{KOCH}^{4}$
}

${ }^{1}$ Universidade Estadual de Campinas, Instituto de Biologia, Programa de Pós-graduação em Ecologia, Campinas, São Paulo, Caixa Postal 6109, CEP 13083-970, Brazil.

${ }^{2}$ Universidade Estadual de Campinas, Instituto de Biologia, Departamento de Botânica, Campinas,

São Paulo, Caixa Postal 6109, CEP 13083-970, Brazil.

${ }^{3}$ Göteborg University, Department of Plant and Environmental Sciences, Göteborg,

P.O.Box 461 SE-405 30, Sweden.
${ }^{4}$ Universidade Federal de São Carlos, Centro de Ciências Biológicas e da Saúde, Av. Darci Carvalho Dafferner, 200, Sorocaba, São Paulo, CEP 18043-970, Brazil.
${ }_{5}^{5}$ Author for correspondence: cfverola@yahoo.com.br

Key Words: Biosystematics, Hoffmannseggella, Laeliinae, endemic species, Campos Rupestres Vegetation, Conservation

\section{Introduction}

In recent molecular studies, the orchid genus Laelia Lindl. was segregated in two main groups: Laelia (a Mexican/Central American group), and Sophronitis Lindl. (a South American group) (van den Berg et al. 2000, van den Berg \& Chase 2000). Later, other studies argued the legitimacy of this classification, suggesting the segregation of the South American group (Sophronitis sensu van den Berg et al. 2000) in four genera: Hadrolaelia (Schltr.) Chiron \& V.P. Castro, Hoffmannseggella H.G. Jones, Dungsia Chiron \& V.P.Castro, and Microlaelia (Schltr) Chiron \& V.P.Castro (Chiron \& Castro 2002).

Hoffmannseggella is one of the most ornamental genus of subtribus Laeliinae and has been shown to be monophyletic (van den Berg et al. 2000). It comprises exclusively rupicolous species and has a scattered distribution confined to the High Altitude Rocky Complexes (Brazilian Campos Rupestres and Campos de Altitude) (Semir 1991, but see discussion in Benites 2003) of Minas Gerais, Rio de Janeiro, Espírito Santo, and Bahia states. Chiron \& Castro (2002) recognized 32 species in the genus, but the number has now increased to 42 (Castro \& Chiron 2003, Chiron \& Castro 2005, Lacerda \& Castro 2005, Miranda \& Lacerda 2003, Mota et al. 2003, Campacci 2005, Miranda 2005, Verola \& Semir in press). Species delimitation is problematic, due to a great polymorphism in floral col- oration and morphology, and the occurrence of natural hybrids (Blumenschein 1960a, 1960b, Brieger 1960, Barros 1990). This study aims at investigating the ecology and evolution of Hoffmannseggella, in order to provide the grounds for a more natural classification of the genus, and increase the knowledge necessary for the management and conservation of its species.

\section{Material and methods}

A multidisciplinary survey with emphasis on floral biology, breeding systems, pollination ecology, phylogeny, biogeography, and divergence times of 13 species of Hoffmannseggella is being conducted based on a varying number of populations.

\section{Results and discussion}

The majority of Hoffmannseggella species in this study does not normally produce nectar or floral odors, but this can vary among populations with fewer than $0.05 \%$ of the individuals in some populations with nectar and/or floral odor production). Generally, each flower lasts seven days on average and the anthesis is sequential racemose with about 3-7 available flowers at the same time. The species recorded so far are pollinated by small and inconstant Hymenoptera (belonging predominantly to families Apidae or Halichitidae), through deceit mechanisms. Bee pollination in Hoffmannseggella contradicts previous suggestions 
(Brieger 1960a, Dressler 1981) which attribute a ornithophilous (in this case hummingbird) syndrome to these plants, but is in accordance with general trends in Laeliinae, where about $60 \%$ of species are pollinated by Hymenoptera (van der Pijl \& Dodson 1966). The pollination by small bees in Hoffmannseggella can be interpreted as an evolutionary innovation in the subtribe, whereas pollination by large bees represents a plesiomorphic condition (Borba \& Braga 2003, Smidt et al. 2006). This shift in pollinator type, accompanied by reduction in floral size and change in coloration patterns, was suggested to have occurred in response to the colonization of a new habitat, the Campos Rupestres (Blumeschein 1960a, Brieger 1960, 1961, 1966). Pollinators generally visit a single flower per inflorescence and the pollination mechanism observed fits the "gullet type" described by Dressler (1981). Visits are sporadic and diurnal, and although they may occur at any time they seem more frequent during warmer periods. Despite population isolation and pollinator scarcity, many species developed (or retained) spontaneous self-pollination mechanisms (Luer 1971, Cattling 1987, Knuth \& Loew 1906) as a way to guarantee sexual reproduction in adverse situations (Catling 1990). The proportion of individuals with these mechanisms vary, with the highest number being found in small and isolated populations.

None of the species studied produced fruits through agamospermy, and fructification rate was generally low. A low rate of fruit formation has been observed in other deceptive orchids (Montalvo \& Ackerman 1987, Ackerman 1989, Zimerman \& Aide 1989) and can be an adaptation to limited resources (Schemske 1980, Montalvo \& Ackerman 1987, Zimerman \& Aide 1989). In these latter studies, species' survivor could only be assured by fruit formation with a high number of seeds (Dressler 1981, 1993).

Breeding systems were observed to vary from selfincompatibility to self-compatibility, depending on the species and population. Fructification and seed viability can vary considerably among populations of the same species. Grant (1975) and Lloyd (1979) pointed out that a great number of species can show mixed breeding systems, from exclusive selfing to outcrossing, including variations of those systems (Barrett et al. 2000, Lande \& Schemscke 1985, Schemscke \& Lande 1985). High seed viability was observed in interspecific crossings, sometimes reaching even higher levels of viability than in cross-pollination experiments. This corroborates the hybridization hypothesis proposed by Blumenschein (1960a, 1960b) and Brieger (1960). Hybridization between synchronopatric species, polyploidy (Blumenschein 1960a, 1960b, Brieger 1960, Barros 1990), and disploidy (see Costa 2006 for a discussion on the same species and populations included in this work) seem to be the main mechanisms triggering radiation in the genus.

Estimates of divergence times in Hoffmannseggella, based on molecular sequence variation, indicate a recent diversification event. The crown age of the genus is placed in the Latest Miocene, and the short ages of several species imply that speciation is still occurring at a high rate (Verola et al. unpubl. data). A high speciation rate seems correlated with the climate oscillation that characterized the Pliocene and Pleistocene, causing the expansion and retraction of open vegetation types (Ledru 2002, Safford 1999). These events promoted high allopatric speciation by vicariance during wet periods, when populations became isolated in the few patches of open vegetation confined to mountain tops. As climate became drier, the expansion of open habitats and establishment of migratory corridors promoted contact between previously isolated species and thus facilitated sympatric speciation (mainly hybridization and polyploidy) (Verola et al. unpubl. data). A similar speciation mechanism has been proposed by other authors, such as Alves \& Kolbek (1994), Pirani et al. (1994), and Semir (1991).

\section{Threats and conservation status}

Similarly to many other plant groups occurring in the Brazilian campos rupestres (Giullieti et al. 2005), the current status of conservation of the species in Hoffmannseggella is precarious. The majority of its species seem to be endangered, as they grow outside protected areas and are thus subjected to grazing, fires, illegal collecting, and habitat destruction. As many as $47 \%$ of the species are micro-endemic (with only one natural population known), and some are known only from the type collection.

The highest species diversity is found in the state of Minas Gerais, in the proximities of Belo Horizonte city. The area is densely populated and comprises a large number of ore prospection fields. Considering the isolation of the area, its high level of endemicity, and poor availability of pollinators, coupled with the great anthro- 
pological pressure on natural populations, the populations occurring in this area appear highly subjected to stochastic events, which may lead to extinction. We therefore suggest the delimitation of fifteen new areas for the conservation of the group's total diversity. These areas were designed considering present and future climate conditions (obtained by the Ecological Modelling Techniques of Beaumont et al. 2005, Hijmans et al. 2004, and Hijmans et al. 2005) as well as centers of endemism (inferred by Parsimony Analysis of Endemicity; Morrone \& Crisci 1995). The suggested areas lay outside current conservation areas, which emphasizes the necessity of an immediate establishment. This study urges for additional works on other taxa characteristic of the Brazilian Campos Rupestres, to better identify regions of range overlaps and thus increase the total number of species per conservation area.

ACKNOWLEDgments. The authors would like to thank IBAMA and IEF for collection permits, Julie Dutilh for improvements in the manuscript and Jardín Botánico Lankester, Universidad de Costa Rica, for publishing this paper. This work was supported by grants from FAPESP (02/08707-1 and 02/08706-5) and CNPq (471742/03-1).

\section{Literature Cited}

Ackerman, J.D. 1989. Limitations to sexual reproduction in Encyclia krugii (Orchidaceae). Syst. Bot. 14: 101-109.

Alves, R.J.V \& J. Kolbek.1994. Plant species endemism in savanna vegetation on table mountains (Campo Rupestre) in Brazil. Vegetatio 113: 125-139.

Barrett, S.C.H., A.M. Baker \& L.K. Jesson. 2000. Matting strategies in Monocotyledons. Pp. 258-269 in: K.L. Wilson $\&$ D.A. Morrison (eds.). Monocots: Systematics and Evolution. CSIRO, Melbourne, Australia.

Barros, F. 1990. Diversidade taxonômica e distribuição geográfica das Orchidaceae brasileiras. Acta bot. bras. 4: 177-187.

Beaumont, L.J., L.Hughes, \& M.Poulsen. 2005. Predicting species distribution: use of climatic parameters in BIOCLIM and its impact on predictions of species' current and future distributions. Ecol. Model. 186: 250-269.

Benites, V.M., A.N. Caiafa, E.S. Mendonça, C.E. Schaefer \& J.C.Ker. 2003. Solos e vegetação nos complexos rupestres de altitude da mantiqueira e do espinhaço. Floresta e Ambiente. 10 (1): 76-85

Blumenschein, A. 1960a. Estudo sobre a evolução no subgênero Cyrtolaelia (Orchidaceae). Livre Docente diss., Universidade de São Paulo / Escola Superior de Agricultura "Luiz de Queiroz"/Esalq, Piracicaba, São Paulo, Brazil.

Blumenschein, A. 1960b. Número de cromossomas de algumas espécies de orquídeas. Publicação Científica do Instituto de Genética, Universidade de São Paulo, Escola Superior de Agricultura "Luiz de Queiroz" 1: 34-44.
Borba, E.L. \& P.I.S. Braga. 2003. Reproductive biology of Pseudolaelia corcovadensis (Orchidaceae): melittophyly and self-compatibility in a basal Laeliinae. Rev. Bras. Bot. 26: 541-549.

Brieger, F.G. 1960. Contribuições para a taxonomia das orquídeas. Publicações Científicas do Instituto de Genética, Esalq, USP 1: 1-31.

Brieger, F.G. 1961. A evolução filogenética nos trópicos. Pp. 154-161 in: F.G. Brieger et al. (eds.). Atas do Primeiro Simpósio Sul Americano de Genética. Cadeira de Citologia e Genética Geral da Escola Superior de Agricultura "Luiz de Queiroz", Universidade de São Paulo, Piracicaba, São Paulo, Brazil.

Brieger, F.G. 1966. Evolução filogenética, com referência especial às plantas superiores. Pp. 464-515. in Pavan, C. \& Da Cunha, A.B. eds. Elementos de Genética. Companhia Editora Nacional \& Universidade de São Paulo, São Paulo, Brazil.

Campacci, M.A. 2005. Duas novas espécies de orquídeas do Brasil. Boletim CAOB 57: 24-31.

Castro Neto,V.P \& G.R. Chiron. 2003. Une nouvelle especè d'Hoffmannseggella (Orchidaceae) du Brésil. Richardiana 3 (1): 64-68.

Catling, P.M. 1987. Notes on the breeding systems of Sacoila lanceolata (Aublet) Garay (Orchidaceae). Ann. Mo. Bot. Gard.74: 58-68.

Catling, P.M. 1990. Auto pollination in Orchidaceae. Pp. 121-158 in: J. Arditti (ed.). Orchid Biology, reviews and perspectives, V. Timber Press, Portland, U.S.A.

Chiron, G.R. \& V.P. Castro Neto. 2002. Révision des espèces brésiliènnes du genre Laelia Lindley. Richardiana 2:4-28.

Chiron, G.R. \& V.P. Castro Neto. 2005. Contribution à la connaissance des orchiées du Brésil. VI - Une nouvelle espèce de Hoffmannseggella du Minas Gerais (Brésil). Richardiana 5 (1): 7-14.

Costa, J.Y. 2006. Citotaxonomia e aspectos evolutivos de espécies de Hoffmannseggella H.G.Jones (Orchidaceae) de campos rupestres brasileiros. Ph. D. diss., Instituto de Biologia, Universidade Estadual de São Paulo, Campinas, Brazil.

Dressler, R.L. 1981. The orchids: natural history and classification. Harvard University Press, Cambridge.

Dressler, R.L. 1993. Phylogeny and classification of the orchid family. Cambridge University Press, Cambridge.

Giullieti, A.M., R.M. Harley, , L.P. Queiroz, , M.G. Wanderley \& C. Van den Berg. 2005. Biodiversidade e conservação das plantas no Brasil. Megadiversidade 1 (1): 52-61.

Grant,V. 1975. Genetics of Flowering Plants. Columbia University Press, New York.

Hijmans, R.J., S.E. Cameron, J.L. Parra, P. G. Jones \& A. Javis. 2004. The WorldClim interpoled global terrestrial climate surfaces. Version 1.3. http://biogeo.berkeley.edu/worldclim/worldclim.htm.

Hijmans, R.J., L. Guarino, A. Jarvis, R. O'Brien, P. Mathur, C. Bussink, M. Cruz, I. Barrantes \& E. Rojas. 2005. Diva- 
GIS. Version 5.2. http://www.diva-gis.org/docs/DIVAGIS5.manual.pdf.

Knuth, P. \& E. Loew. 1906. Handbook of flower pollination. Claredon Press, Oxford.

Lacerda Jr., K.G. \& V.P. Castro Neto. 2005. Deux nouveaux taxons de Hoffmannseggella du Minas Gerais (Brésil). Richardiana 5 (1): 15-25.

Lande, R. \& D.W. Schemske. 1985. The evolution of self-fertilization and inbreeding depression in plants. I. Genetic models. Evolution 39:24-40.

Ledru, M.P. 2002. Late Quaternary history and evolution of the cerrados as revealed by palynological records. Pp. 33-50 in: P.S. Oliviera \& R.J. Marquis (eds.). The cerrados of Brazil. Columbia University Press, New York, USA.

Lloyd, D.G. 1979. Some reproductive factors affecting the selection of self-fertilization in plants. Amer. Natur. 113:67-79.

Luer, C.A. 1971. Abnormal development of the anther - a report of two cases. Florida Orchidist 13: 26-29.

Miranda, F. \& Jr., K.G. Lacerda. 2003. Studies in Brazilian Laeliinae. Part 1: New species and natural hybrids in Hoffmannseggella. Orchids 72 (11): 848-857.

Miranda, F. 2005. Studies in Brazilian Laeliinae. Part 2: A new species in Hoffmannseggella. Orchids 74 (6): 458-461.

Montalvo, A.M. \& J.D. Ackerman. 1987. Limitations to fruit production in Ionopsis utricularioides (Orchidaceae). Biotropica 19: 24-31.

Morrone, J.J. \& J.V. Crisci. 1995. Histórical Biogeography: Introductin to Methods. Annu. Rev. Ecol. Syst. 26: 373-401.

Mota, R.C., P.L. Viana \& K.G. Lacerda Jr. 2003. Hoffmannseggella pendula, une nouvelle espèce d'Orchidaceae du Brésil. Richardiana 4 (1): 1-8.

Pirani, J.R., A.M. Giulietti, R. Mello-Silva \& M. Meguro. 1994. Checklist and patterns of geographical distribution of the vegetation of Serra do Ambrósio, Minas Gerais, Brazil. Rev. Bras. Bot. 17 (2): 133-147.

Safford, D.S. 1999. Brazilian Páramos I. An introduction to the physical environment and vegetation of the campos de altitude. J. Biogeogr. 26: 693-712.

Schemske, D.W. \& R. Lande. 1985. The evolution of self-fertilization and inbreeding depression in plants. II. Empirical observations. Evolution 39:41-52.

Schemske, D.W. 1980. Evolution of floral display in the orchid Brassavola nodosa. Evolution 34: 489-493.

Semir, J. 1991. Revisão Taxonômica de Lychnophora Mart. (Vernonieae:Compositae). Ph. D. diss., Instituto de Biologia, Universidade Estadual de São Paulo, Campinas, Brazil.

Smidt, E.C., V. Silva-Pereira \& E.L. Borba. 2006. Reproductive biology of two Cattleya (Orchidaceae) species endemic to north-eastern Brazil. Plant Species Biology 21: 85-91.

van den Berg, C. \& M.W. Chase. 2000. Nomenclatural notes on Laeliinae - I. Lindleyana 15: 115-119.

van den Berg, C., W.E. Higgins, R.L. Dressler, W.M. Whitten, M.A.S. Arenas, A. Culham \& M.W. Chase. 2000. A phylogenetic analysis of Laeliinae (Orchidaceae) based on sequence data from internal transcribed spaces (ITS) of nuclear ribosomal DNA. Lindleyana 15: 96-114.

van der Pijl, L. \& C.H. Dodson. 1966. Orchid flower: their pollination and evolution. University of Miami Press, Coral Gables.

Verola, C.F. \& J. Semir. 2007. Hoffmannseggella viridiflora (Orchidaceae, Laeliinae), A New Species from Brazilian Campos Rupestres. Novon (accepted)

Zimmerman, J.K. \& T.M. Aide. 1989. Patterns of fruit production in a neotropical orchid: pollinator vs. resource limitation. Amer. J. Bot. 76: 67-73.

Christiano Franco Verola was born in Brazil in 1977. He graduated in biological sciences at Universidade Estadual Paulista "Júlio de Mesquita Filho" and received his M. Sc. in ecology at Universidade Estadual de Campinas. His research interests concern breeding systems, floral biology, pollination mechanisms, and pollination ecology in Bulbophyllum and Hoffmannseggella species (Orchidaceae). He is currently concluding his PhD thesis dealing with biosystematics studies in Hoffmannseggella species.

João Semir graduated and received his M. Sc. at Universidade de São Paulo. Later he wrote a PhD thesis dealing with the taxonomy of Lychnophora (Asteraceae). Since then, he has been working with the systematics of several groups from the Brazilian Campos Rupestres, including the Orchidaceae, Asteraceae, Bignoniaceae, and Melastomataceae. Today, he is a teacher and researcher at Universidade Estadual de Campinas and is involved in taxonomic projects concerning the Brazilian Flora, such as Flora Fanerogâmica do Estado de São Paulo.

Alexandre Antonelli was born in Brazil in 1978. After undergraduate studies in biology at Universidade Estadual de Campinas and Université de Genève, Switzerland, he received his M. Sc. in plant systematics at University of Göteborg, Sweden. He is now working on his $\mathrm{PhD}$ thesis concerning the systematics and historical biogeography of Neotropical plants.

Ingrid Koch graduated in biology at Universidade Estadual Paulista “Júlio de Mesquita Filho". She received her M.Sc. and $\mathrm{PhD}$ in plant biology at Universidade Estadual de Campinas, in which she conducted taxonomic studies in Apocynaceae. In her post-doc, she worked with GIS and Ecological Modeling applied to plant distribution and conservation, at Centro de Referência em Informação Ambiental (CRIA) in Campinas. Today she collaborates in various botanical projects, one of which investigates the taxonomy of Neotropical Apocynaceae. She also acts as a teacher at Universidade Estadual Paulista "Júlio de Mesquita Filho" and project assistant at Universidade Estadual de Campinas. 